\title{
The Impact of Mind-Mapping Method to Student's Career Decision-Making
}

\author{
Sovi Septania ${ }^{1 *}$, Tansri Adzlan Syah ${ }^{1}$ \\ ${ }^{I}$ Psychology Faculty, Muhammadiyah Lampung University, Bandar Lampung, Indonesia \\ *Corresponding author. Email: sovi.septania@gmail.com
}

\begin{abstract}
Technology is constantly changing the way we work which will emphasize variance of work itself. It created a host of new position of job which never before existed. The career options available today is nothing like they were 20 years ago. Career decision-making present an important role to endorse productive and precise career in the future. In other side, mind-mapping as a powerful tool is design to maximize career ideas, create concepts which can turn to career prototype to have a more concrete directions to test their prototype. The focus of this research was to determine the effect of mind-mapping methods on career decision-making on Psychology faculty's student in Muhammadiyah Lampung University. Research design using quasiexperimental one group pre-test \& post-test design with 26 students as experiment group based on the prescreening results. Research instrument used is career decision-making scale adapted from Betz's theory (2004). The results showed that mind-mapping method had significant effect on career decision-making with paired samples t-test results with $\mathrm{t}$ score $-6,405(\mathrm{p}<0.05)$. The average gain score before treatment was 91.61 increased to 103 after treatment. The goal selection aspect had a higher final total score with 546 score compared to other aspects. Therefore, mind-mapping method significantly influences the final goal selection process which is closely related to student career decision-making. The implication of this research will further enhance the use of mind-mapping methods as a more practical tools for decision making.

Keywords: mind-mapping, career decision-making, students
\end{abstract}

\section{INTRODUCTION}

High technology increased along with unlimited access by all human, encourages some evolution in all aspects in life, including world of work. The world of work has many contexts which one of them is industrial area. One of the biggest challenges nowadays in industrial area is the beginning of Industrial Revolution 4.0 which becoming a unique phenomenon compared to previous three industrial revolution. Industrial revolution 4.0 itself provides a golden opportunity for competitors who are able to prepare themselves in facing all the changes which predicted to happen. Potential benefits of Industrial 4.0 such as higher speed improvements of production flexibility, higher customer service demand and significant increasing for revenue. The realization of those potential benefits will create positive impact on national economy [1].

There are ten aspects in Industrial Revolution 4.0 consists of standardization, modeling, communication networks, safety security, human resources, law, human resource efficiency, cyber-physical system (CPS) technology, smart factory, business, work design, services, organizational management and end-to-end production engineering [2]. Based on those aspects, human resources system takes important role for succession in Industrial 4.0. Unlocking the important role of human resources, triggering higher need of potential human capital. Targeting the unlimited potential of human resources will increase productivity improvement and skilled workforce [3].

We are living the future of work currently [4]. Despite the headlines predicted the loss of jobs due to automation, artificial intelligence (AI), machine learning and autonomous system, it is clear that we are transforming the way we work and live. The unnerving evolution is coping by systematic awareness on how work will likely change and some constructive idea for how prepare for it. Build upon this need, strategic and robust preparedness is needed. Intended preparation starts from each prospective workforce to build human's potency align with background education generate highly competitive candidates in the future. This is closely related to career planning and decision-making.

Career is defined as a sequence's positions related to work, roles, activities and experiences faced by someone [5]. Opportunity to do work which demands their creativity, imagination, social and emotional intelligence and passion. In addition, employees need to shape their career path by pursuing their passion adapting with the constant changing in technology.

For students, shaping career begin while choosing majors in university. Early career preparation certainly ensures the alignment between academic and practical value with right career decision-making. Career decision-making process is surely not easy for students since they must try to overcome the uncertainty about their capabilities, interest stability, alternative prospect for current and future choices, career accessibility and finalize the identification for themselves [6]. This will cause many doubts before settlings on career path for students [7]. Early career preparation certainly ensures that there is stability in making the right career 
decisions so that the academic and practical values needed to face high competition can be optimized especially when still in the higher education environment. The career decision-making process is certainly not easy because individuals must try to overcome the uncertainty about their capabilities, the stability of interests, alternative prospects for current and future choices, career accessibility and identity that they want to develop [6].

One's career development is marked by the widespread assessment of various problems in deciding what work to do in the future [8]. This ended with career decision making. Career decision making is a process in which a person makes a selection of several choices in future plans. This is in line with the explanation which states that the career decision in question is a decision taken wisely and full of study and consideration [9]. Decision making like this is absolutely necessary for the success of his life later with the chosen career.

Students who have taken higher education, of course, want success in pursuing a career after being declared graduated. Besides having an adequate life gap, self-satisfaction in self-actualization becomes the main goal for students when facing the real world of work. For this reason, adequate career preparation, including the accuracy of career decisions so that what is owned (potential) is in accordance with what is desired [10]. Skills in making career decisions are needed so that accuracy in deciding the career to be selected and can be achieved. Because of the importance of career decision making, in-depth guidance is needed in the process. Career decision making is an important skill that can be learned. The stages in the career decision-making process are traversed by identifying and processing information skills [11].

A theory highlight person's career development and decision-making process is Cognitive Information Process (CIP) developed by Peterson, Sampson and Reardon) [12]. Career as a decision tree illustrates the decision points faced by a person through school so as to enter the workforce; as a series of stages of life in which various constituents of developmental tasks are encountered. Making a decision tree can be developed through the mind-mapping method. Mind-mapping will help student to see the big picture of their plan by comparing their current position and what is expected or achieved. It helps students to make a robust planning since one of strong function of mind-mapping is to facilitate planning [13].

The significance of this research is expected to provide an overview, information and advice on the application of mind-mapping methods in influencing students' future career decision-making ability.

\section{METHOD}

\subsection{Subject}

Subjects of this study were 86 students in Psychology Faculty, Muhammadiyah Lampung University, Indonesia. All students were given career decision-making scale according to Betz's theory consisting five aspects include self-appraisal, occupational information, goal, planning and problem solving.

Subject were selected with purposive sampling with criteria active student in Psychology Faculty, Muhammadiyah Lampung University and unemployed. Total subjects consist of 82 students. Further step was determining experimental group by giving pretest to all subjects.

Data for career decision-making scale pretest were analyzed based on total score obtained by students. The criterion of level in career decision-making for high level with 102 minimum score, medium level with range score 92-102 and low level with 91 minimum score. Based on this preelementary screening, result showed that 56 students were in high level, 15 students in medium level, and 11 students in low category of career decision-making. Therefore, 26 students in medium and low level will treated as experiment group.

\subsection{Research Design}

This research used quasi one-group pre-posttest design. This design was initially carried out measurement of dependent variable owned by subjects, and after treatment, measurement was analyzed to dependent variable with the same measuring instrument. The effectiveness of mindmapping method on career decision-making is seen from the score difference between pretest and posttest with paired-sample-t-test statistical analysis. With pretest result, initial position of each subject was determined to have proactive history of each subjects. Based on pre-elementary result of career decision-making scale, 26 students were included as experiment group for further treatment.

\subsection{Mind-Mapping Method}

Mind-mapping is commonly defined as creative thinking tools and reflect how brain work [10]. Mind-mapping method allow brain to use images and their associations in radical patterns. This understanding show similarity between how mind-mapping method work with how brain work.

Implementing mind-mapping in daily basis is based on the natural workings of the brain and is able to ignite the spark of creativity in human brain since it involves both hemispheres of the brain. Mind-mapping method uses visual and sensory reminders in a pattern of ideas. It also maximizes the use of visual imagery and other graphic infrastructure to form impression on the brain [14].

Several advantages from mind-mapping methods could intensify student productive behavior such as becoming more creative, time efficiency, problem solving, concentrating, organizing and clarifying thoughts, faster memorizing, more efficient in seeing overall picture and making plans. Thus, mind-mapping free students to be creative in mapping their thought.

In this study, we use general standard for mind-mapping method. Seven steps in making mind-mapping are:

a. Start from the middle surface of the paper in landscape position. It aims to provide flexibility for brain to work 
to spread out in all direction and to express themselves freely and naturally.

b. Using images as central ideas. Picture is worth a thousand words and can maximize human's imagination. By giving images in the center of the paper, it looks more interesting and stimulate brain to be more creative.

c. Using colours. Brain is very interested in colors. Mindmapping will look brighter and more alive; hence it will increase the power of creative thinking and more fun.

d. Connect to main branches to the central image. The inter connection between branches will stimulate human to do associations. Namely, by connection branches, it will be easier to remember and understand the whole picture's connection.

e. In making branches, using curved line instead of straight line. Straight lines will bore our brains, while curved branches are more attractive and more fun to see.

f. Use one keyword per line. A single keyword will make mind-mapping method more powerful and flexible. By using a single word, will generate various and new ideas.

g. Using images. One picture in mind-mapping is worth 1000 words.

The implementation of the action treatment with mindmapping training was done with the steps as follows. (1) preparation steps consist of administrative and module preparation. (2) preliminary assessment and selection of research subject. (3) informed consent registration. (4) mind-mapping active training.

Mind-mapping active training was conducted in 4 hours duration divided into four sessions. (1) Opening session focus on how facilitator explain the purpose of training, participants are given an explanation the series of training sessions and the objective of each session. This opening session was aim to build good rapport between facilitator and participants. (2) Career brainstorm session which focus on group discussion about difficulties on career planning. Facilitator give insight on the definition of career, aspects of career decision-making, problem and potential action plan when those problems occurs. The main purpose of second session is to identify participants' problem and to bring insight the importance of career decision-making. (3) Mind-mapping practice session. Facilitator guide participants in making mind-mapping and provide feedback on the meaning of the practice. At the end of this session, participants were asked to share their personal mindmapping result linked with career decision-making in the future. Facilitator emphasize the use of mind-mapping methods in several usability. (4) Review session focus on evaluating the whole training session and participants perform posttest by using career decision-making scale which is the same instrument used as pretest.

\section{RESULT}

Based on score on categorization data, it shows that there is an increase in career decision-making on subjects after the mind-mapping training. Analysis show that pretest result put $42 \%$ or 11 subjects in low level of career decisionmaking, and $58 \%$ or 15 subjects in medium level of career decision-making. Based on posttest after treatment, data analysis show score increases with $38 \%$ or 10 subjects in medium level of career decision-making and $62 \%$ or 16 subjects in high level of career decision-making.

Based on total gain score, there was 288 score increase with 11.07 average score for each subject after treatment. Namely the average gain score before treatment show 91.61 score and increase into 103 score after treatment. Minimum value before treatment is 66 with maximum value 101. After treatment, minimum value rises to 88 and maximum value rises to 117 .

Data normality pretest and posttest scores using Kolmogorov-Smirnov method are normally distributed as indicated by the acquisition of normality index value 0.078 with significance value $0.200(p>0.005)$ for pretest data, while posttest data show normality index value 0.111 with significance value $0.200(\mathrm{p}>0.05)$.

Data homogeneity based on Levene's test show that $p$ value $0.173(p>0.05)$ and Levene's statistic value 4523 which means the distribution of pretest data is homogeneous. Posttest data show $p$ value 0.467 ( $p>0.05)$ with Levene's statistic value 1.006 which also means distribution of posttest data is homogeneous.

Hypothesis analysis used in this study is statistical analysis using paired-t-test. Hypothesis proposed is that there is an impact of mind-mapping method on student's career decision-making with 95\% confidence level and an error rate of $5 \%(0.05)$. Hypotheses will be accepted if the significance level is smaller than the error rate $(0.05)$. Result of paired-t-test show t score -6.405 with significance value $0.000(\mathrm{p}<0.05)$. There was very significance difference between mean pretest and posttest, and therefore, the hypothesis is accepted.

The goal selection aspect showed highest final total score with 546 score compared to other aspects. Self-appraisal total score 461, occupational informational total score 518, planning total score 414 and problem-solving total score 465. Therefore, mind-mapping method significantly influences the final goal selection process which is closely related to student career decision-making. This is accordance with the main objective of mind-mapping method training process which will encourage participants to make selection process more precisely. The finale result is obtained, namely career decision-making.

The concept of career selection is a major concept that has three main factors in the decision-making process, namely a clear understanding of oneself, knowledge of the conditions and prospects in various lines of work and correct reasoning about the relationship between these two fact groups [15]. By involving an appropriate method, then someone will more easily determine career planning that ends with the right decision-making.

Mind-mapping method involves the right and left brain in a balance way [16]. The main advantage of mind-mapping is the principle how it works depend on what the brain wants. 
[3] Rüßmann, M., Lorenz, M., Gerbert, P., Waldner, M., Justus, J., Engel, P. \& Harnisch, M. (2015). Industry 4.0: The future of productivity and growth in manufacturing industries. Boston Consulting Group, p.14.

[4] Marr, Bernard. (2019). The Future Of Work: 5 Important Ways Jobs Will Change In The 4th Industrial Revolution. Forbes.com (diakses pada tanggal 26 September 2019)

[5] Kidd, J. M. 2006. Understanding Career Counseling Theory Research and Practice. London: Sage Publication.

[6] Bandura, A. (2012). Self-efficacy. The exercise of control. New York: Freeman

[7] Creed, P., Patton, W., \& Prideaux, L. (2006). Causal relationship between career indecision and career decision-making self-efficacy. Journal of Career Development, 33(1), 47-65.

[8] Sunarto, H., Hartono. (1995). Perkembangan Peserta Didik. Jakarta: PT. Rineka Cipta.

[9] Munandir. (1996). Program Bimbingan Karier Di Sekolah. Jakarta: Jalan Pintu Satu.

[10] Sharf, R. S. 2002. Applying Career Development Theory to Counseling. California: Brooks and Cole Publishing

[11] Zunker, V.G. (2006). Career counselling: a holistic approach. Singapore: Thompson

[12] Buzan, Toni. (2008). Mind Map untuk Meningkatkan Kreativitas. Jakarta: Gramedia Pustaka Utama.

[13] Buzan, Toni. (2006). Buku Pintar Mind mapping. Jakarta: Gramedia Pustaka Utama.

[14] DePorter, B., \& Hernacki, M. (2007). Quantum Learning: Membiasakan Belajar Nyaman dan Menyenangkan. Bandung: Kaifa.

[15] Nathan, Robert \& Hill, Linda. (2012). Konseling Karier. Yogyakarta: Pustaka Pelajar

[16] Windura, Sutanto. (2010). Mind Map: Langkah Demi Langkah. Jakarta: Elex Media Komputindo

[17] Widiana, I Wayah., \& Jampel, I Nyoman. (2016). Improving Students' Creative Thinking and Achievement throug the Implication of Multiple Intelligence Approach with Mind Mapping. International Journal of Evaluation and Research in 
Education (IJERE) Vol. 5, No. 3 September 2016, pp 246-254

[18] Jones, Bret D., Ruff, Chloe., Snyder, Jennider Dee., Petrich, Britta., \& Koence, Chealse. (2012). The effect of Mind-mapping Activities on Students' Motivation. International Journal of Scholarship of Teaching and Learning Vol. 1, No. 6, pp 1-19 